\title{
Perilaku Sosialisasi Anak Ditinjau dari Latar Belakang Keluarga
}

\author{
Rida Sinaga \\ Sekolah Tinggi Agama Kristen Terpadu Pesat, Salatiga, Jawa Tengah, Indonesia \\ ridasinaga@gmail.com
}

\begin{abstract}
The article entitled "The Behavior of Children Socializing Viewed by Family's Background" focuses on the social behavior of children carried out in Integrated Bina Kasih Kindergarten in Rumah Sumbul Village, Sibolangit. The research method used a descriptive qualitative method. Data collection through observation and interviews with parents. Observation using observation sheets. Child socialization behavior observed in children based on family background, namely adjusting the place, making friends, sympathy and empathy, cooperative, and manners. While the family background is focused on parental education, employment, income, parental integrity, and a number of children. This study found that children with a good family background were found to have a tendency towards good socialization behavior and children who had a poor family background tended to have poor socialization behavior. This shows that family background has a strong relationship in the development of children's socialization behavior. The existence of parents really determines the way they treat children and that too is then embedded and developed in children.
\end{abstract}

Keywords: early childhood; Family's background; socialization behavior

\begin{abstract}
Abstrak
Artikel yang berjudul "Perilaku Sosialisasi Anak Ditanjau Dari Latar Belakang Keluarga" fokus pada perilaku sosial anak yang dilakukan di Taman Kanak-Kanak Bina Kasih Terpadu di Desa Rumah Sumbul, Sibolangit. Metode penelitian yang dilakukan adalah dengan metode kualitatif deskriptif. Pengumpulan data melalui pengamatan dan wawancara kepada orang tua. Pengamatan menggunakan lembar observasi. Perilaku sosialisasi anak yang diamati dalam diri anak berdasarkan latar belakang keluarga, yaitu penyesuaian tempat, berteman, simpati dan empati, kooperatif, dan sopan santun. Sedangkan latar belakang keluarga difokuskan pada pendidikan orang tua, pekerjaan, penghasilan, keutuhan orang tua, dan jumlah anak. Penelitian ini menemukan bahwa anak dengan latar belakang keluarga yang baik didapati memiliki kecenderungan perilaku sosialisasi baik dan anak yang latar belakang keluarga kurang baik cenderung memiliki perilaku sosialisasi yang kurang baik. Hal ini menunjukkan bahwa latar belakang keluarga memiliki hubungan yang kuat dalam perkembangan perilaku sosialisasi anak. Keberadaan orang tua sangat menentukan cara mereka memperlakukan anak dan hal itu pula yang kemudian tertanam dan berkembang dalam diri anak.
\end{abstract}

Kata kunci: anak usia dini; latar belakang keluarga; perilaku sosialisasi 


\section{PENDAHULUAN}

Seorang anak membutuhkan orang lain untuk mengasuh dan memelihara agar dapat mencapai pertumbuhan yang maksimal dan wajar dalam seluruh aspek kehidupannya. Orang lain yang paling dekat dengan anak adalah keluarga, khususnya orang tua yang telah diberi kepercayaan oleh Allah untuk membesarkan, memelihara dan mengasuh anak. Dalam keluarga anak dilahirkan dan dibesarkan, jadi tidak berlebihan kalau keluarga merupakan wadah yang tepat atau lembaga pengasuhan yang paling dapat memberi kasih sayang dan perhatian penuh pada anak. Keberadaan keluarga menjadi tempat yang penting untuk anak berkembang dan bertumbuh. Lingkungan keluarga juga adalah sebagai tempat pertama dan utama terjadinya sosialisasi anak, karena sosialisasi sudah dimulai sejak anak lahir. Sebagaimana yang diungkapkan Wiriadtmaja: "Proses sosialisasi dimulai sejak anak dilahirkan supaya anak dapat mengetahui dan memperoleh sikap, pengertian, gagasan, dan pola tingkah laku yang disetujui oleh masyarakat. Sebagai makhluk sosial yang tidak dapat hidup sendiri, anak membutuhkan cinta, kasih, dan perhatian untuk bertumbuh secara wajar" . Kemampuan untuk menjalin hubungan dengan sesama, mudah menyesuaikan diri dengan lingkungan dan orang baru tidak terlepas dari bagaimana seseorang berinteraksi dengan orang-orang di sekitarnya. Inilah yang disebut dengan perilaku sosialisasi. Keberadaan keluarga tempat anak dibesarkan menjadi faktor penting dalam menumbuhkan perilaku sosialisasi anak.

Ada pendapat yang mengatakan bahwa orang sukses adalah orang yang memiliki perilaku sosialisasi yang baik (cerdas sosial), seperti yang diungkapkan oleh Jarot Wijanarko: "Anak yang pandai bersosialisasi, adalah anak yang akan berhasil di kemudian hari." "2 Menyoroti pentingnya kepandaian bersosialisasi Prasetya berpendapat, bahwa 85\% keberhasilan ditentukan oleh kecerdasan yang berkaitan dengan relasi manusia baik dengan diri sendiri maupun orang lain, keahlian atau ketrampilan teknis hanya $15 \%{ }^{3}$ Kemampuan untuk memahami dan berkomunikasi dengan diri sendiri dan orang lain jauh lebih baik dan penting di banding dengan keahlian teknis. Hal ini dapat diamati dari orang-orang dalam profesi yang sama, tidak jarang ada yang berhasil dan ada pula yang gagal; bukan karena yang satu lebih pintar dibandingkan yang lain, namun lebih cenderung pada kemampuan berelasi dengan orang lain dibandingkan yang lain. ${ }^{4}$

Anak tidak dapat menjadi makhluk sosial yang baik tanpa pendampingan yang baik dari orang tua. Anak bisa berkembang menjadi apa saja di tangan orang tua, lewat bimbingan, arahan dan pengaruh yang intens. Wiriatmaja mengatakan bahwa anak dapat

\footnotetext{
${ }^{1}$ Soekandar Wiriadtmaj, Pokok-Pokok Sosiologi Pedesaan ( Bandung: CV.Yasa Guna, 1987 ), 28

${ }^{2}$ Jarot Wijanarko, Anak Cerdas Ceria Berakhlak ( Jakarta: Happy Holy Kids, 2007 ), 57

${ }^{3}$ GeorgeTembong Prasetya, Smart Parenting, ( Jakarta : PT Elex Media Komputindo, 2006 ), 4

${ }^{4}$ Ibid., 6
} 
dipengaruhi, apabila anak diberikan hal-hal yang baik dan benar, maka hal tersebut akan bertumbuh dalam pribadi anak. Itu juga yang akan diterapkan oleh anak ketika bersama dengan orang lain. Jika pada masa-masa awal, anak diberi landasan yang kuat tentang kebenaran, kemungkinan untuk salah arah akan lebih kecil bagi mereka. ${ }^{5}$ Gunarsa mengatakan: "Keluarga adalah sumber stimulasi untuk mempengaruhi perkembangan anak dan karena itu stimulasi ini bisa diatur, diarahkan oleh orang tua sehingga arah perubahan dan perkembangan anak dapat terarah sesuai dengan yang diharapkan." ${ }^{6}$ Keluarga yang memiliki latar belakang baik, dalam hal: pendidikan, penghasilan, utuh, pekerjaan baik dan menerapkan pola asuh yang tepat, memungkinkan untuk dapat memberikan bimbingan dan arahan yang lebih baik dalam perkembangan anak. Itu sebabnya baik juga dipertimbangkan adanya edukasi yang tepat bagi orang dewasa di gereja, agar mereka dapat memberikan pendidikan yang baik dan benar juga kepada anak-anak mereka. ${ }^{7}$ Hal ini akan memberikan dampaik yang signifikan bagi perkembangan anak, baik secara fisik maupun sosialnya.

Perilaku sosialisasi tidak tercipta begitu saja, tetapi perlu ditumbuhkan dan dibina sejak anak masih kecil. Keterlibatan keluarga khususnya orang tua sangat berperan dalam pembentukan perilaku sosialisasi anak. Ada anak-anak yang perlu perhatian khusus dalam proses pendidikannya. ${ }^{8}$ Hal tersebut menimbulkan keinginan penulis untuk mengetahui bagaimana perilaku sosialisasi anak anak di TK Bina Kasih yang ada di Desa Rumah Sumbul Kecamatan Sibolangit, ditinjau dari latar belakang keluarga anak yang berperan besar menumbuhkan perilaku sosialisasi dalam pribadi anak.

Pengamatan terhadap keadaan anak-anak di TK Bina Kasih memperlihatkan perbedaan yang sangat mencolok. Ada beberapa anak yang sangat pemalu dan takut kalau bertemu dengan orang yang baru, suka menyendiri, tidak mau bermain dengan yang lain dan sulit berpisah dengan orang tuanya. Awal masuk sekolah mereka harus ditemani orang tua di sekolah selama beberapa hari. Bahkan ada anak yang ditunggui orang tua di sekolah sampai tiga minggu. Ada juga anak yang sangat berani, supel, ceria, senang berteman dan bermain bersama, tidak canggung dengan tempat dan orang yang baru dikenal. Hal yang sangat menyolok ini menimbulkan ketertarikan untuk meneliti apa yang menyebabkan ada anak yang sangat pemalu, penakut berada di tempat yang baru dan bertemu orang baru, tetapi sebaliknya ada yang berani dan bersikap biasa saja.

\footnotetext{
${ }^{5}$ Soekandar Wiriadtmaja, Pokok-Pokok Sosiologi Pedesaan (Bandung: CV.Yasa Guna, 1987 ), 28

${ }^{6}$ Singgih Gunarsa, Yulia Singgih Gunarsa, Psikolgi Praktis: Anak, Remaja dan Keluarga (Jakarta: BPK Gunung Mulia, 2004), 2

${ }^{7}$ Johanes Waldes Hasugian, "Kurikulum Pendidikan Kristen Bagi Orang Dewasa Di Gereja," Kurios: Jurnal Teologi dan Pendidikan Agama Kristen 5, no. 1 (2019): 36-54.

${ }^{8}$ Johanes Waldes Hasugian et al., "Education for Children with Special Needs in Indonesia," Journal of Physics: Conference Series 1175, no. 1 (2019).
} 
Berdasarkan latar belakang tersebut di atas, maka tulisan ini diberi judul: Perilaku Sosialisasi Anak ditinjau dari Latar Belakang Keluarga. Adapun tujuannya adalah untuk mendeskripsikan perilaku sosialisasi anak ditinjau dari latar belakang keluarga.

\section{Kajian Teoritis}

Perilaku adalah reaksi terhadap lingkungan dimana seseorang berada. Menurut Kamus Bahasa Indonesia, kata perilaku memiliki arti: "Tanggapan atau reaksi seseorang terhadap lingkungan, orang-orang di sekitar di mana ia berada." 9 Sementara, kata sosialisasi adalah: "Kemampuan bergaul anak maksudnya bagaimana seorang anak dapat berteman dengan anak-anak lain, supaya anak dapat dengan sukacita berada di antara teman-temannya." "10 Sosialisasi adalah kemampuan bergaul anak melalui interaksi dengan teman-teman di lingkungannya. Jadi seorang anak harus dapat beradaptasi dan membawa diri pada lingkungan di mana berada. Perilaku sosialisasi yang dimaksud adalah kemampuan anak dalam membangun hubungan, berinteraksi, juga dalam bergaul dengan teman sebaya atau dengan orang dewasa. Sikap dan perilaku anak sehari-hari turut mendukung apakah seorang anak akan diterima oleh teman-temannya atau mungkin ditolak lingkungan. Dalam penelitian ini aspek-aspek perilaku sosial anak yang diteliti adalah: penyesuaian sosial ${ }^{11}$, kooperatif, simpati empati, berteman ${ }^{12}$, dan sopan santun. Semua ini adalah hal yang sangat perlu bagi anak dan bagi semua orang dalam berinteraksi dengan orang lain. ${ }^{13}$

Keluarga bertanggung jawab dalam menjaga dan menumbuhkembangkan anggotaanggota keluarga. Keluarga khususnya orang tua diharapkan dapat mempersiapkan anakanak agar dapat menjalankan kehidupan masa depan mereka dengan baik. Peranan orang tua sangat besar dalam membantu anak agar dapat berkembang secara wajar, dan siap memasuki gerbang kehidupan mereka di masa yang akan datang di tengah masyarakat yang sangat kompleks. Orang tua mempunyai kesempatan dan peluang yang besar untuk membentuk seorang anak menjadi anak yang mandiri, anak yang mengerti sopan santun, anak yang dapat bergaul, bermain bersama dengan anak lain, dan berinteraksi dengan orang-orang di sekitarnya serta menjadi anak yang tidak egois atau mementingkan diri sendiri. Dorothy Einon: Perkembangan sosialisasi anak usia 4-6 tahun jika mendapat bimbingan dan asuhan yang tepat maka anak akan bertumbuh dan berkembang secara optimal dalam perilaku sosialnya. Dalam usia ini anak akan senang berteman, bermain bersama-sama teman-teman sebaya, mulai mengerti bahwa orang lain mempunyai pikiran, perasaan yang berbeda. Jika penerapan nilai-nilai telah dimulai sejak usia dini sebelumnya

\footnotetext{
${ }^{9}$ Departemen Pendidikan Nasional, Kamus Besar Bahasa Indonesia (Jakarta: Balai Pustaka, 2001 ), 859

${ }^{10}$ Hendra Surya, Percaya Diri itu Penting ( Jakarta: PT Elexmedia Komputindo, 2007), 125

${ }^{11}$ Elizabeth B. Hurlock, Psikologi Perkembangan Jilid I ( Jakarta: Erlangga, 2003 ), 287

${ }^{12}$ Elizabeth B. Hurlock, Psikologi Perkembangan Jilid II ( Jakarta: Erlangga, 2004 ), 118-119

${ }^{13}$ Sylvia Rim, Mendidik dan Menerapkan Disiplin Pada Anak Prasekolah ( Jakarta: Gramedia Pustaka Utama, 2003 ), 30
} 
maka anak sudah dapat memahami dan melakukannya ketika ia berada diantara temanteman sebayanya.

Beberapa fungsi keluarga dalam usaha mendewasakan anak menurut Kartini Kartono adalah: fungsi protektif, biologis, afektif, rekreatif, ekonomis, sosialisasi, edukatif, sivilisasi, dan religius. ${ }^{14}$ Fungsi protektif yaitu melindungi anak dari macam-macam mara bahaya dan pengaruh buruk dari luar maupun dari dalam, serta melindungi anak dari ketidakmampuan menyesuaikan diri terhadap lingkungan sekitar. Fungsi biologis mencakup pemenuhan segala kebutuhan vital biologis segenap anggota keluarga, memelihara, merawat anak agar kesehatan dan pertumbuhannya terjamin. Fungsi afektif memberikan cinta kasih, kehangatan, respek, kepercayaan, kelembutan, dan keakraban yang merangsang tumbuhnya macam-macam emosi dan sentimen positif terhadap anak di sekitar anak-anak. Fungsi rekreatif menciptakan suasana rumah tangga yang intim, hangat, ramah, bebas, santai, damai, dan menyenangkan, agar semua anggota keluarga betah tinggal di rumah.

Fungsi ekonomis meliputi pemenuhan kebutuhan sehari-hari, termasuk biaya perawatan dan pendidikan anak. Fungsi sosialisasi, memersiapkan anak-anak menjadi manusia sosial dan menjadi anggota masyarakat yang baik mau bertanggung jawab untuk kesejahteraan umum, memperkenalkan tata cara kehidupan masyarakat dan memberikan bekal kemampuan untuk beradaptasi terhadap lingkungan sosial. Fungsi edukatif membawa anak pada kedewasaan kemandirian, pertanggungjawaban, pengenalan nilai-nilai moral dan kewajiban untuk melakukan tugas-tugas hidup sebagai manusia terdidik. Fungsi sivilisasi, yaitu memperkenalkan anak pada norma-norma hukum, larangan, keharusan, kewajiban, dan norma-norma peradapan. Fungsi religius mengajak anak untuk memiliki keimanan kepada Tuhan.

Dalam mendidik anak tingkat pengetahuan orang tua juga turut menjadi faktor pendukung yang penting. Bagi orang tua yang berpendidikan, tahu hal-hal baik yang perlu diterapkan kepada anak. Hal tersebut berguna bagi kehidupan anak di masa yang akan datang, baik dalam keluarga maupun di tengah masyarakat. Menurut Soemiarti Padmonodewo "Dengan adanya pendidikan yang dimiliki orang tua, berarti peran dan tanggung jawab menjadi lebih baik. Pengetahuan dan keterampilan yang baik akan mengubah pola pikir dan sikap orang tua sebagai pendidik terhadap anak."15 Orang tua yang tidak berpendidikan, tidak mengerti cara mendidik dan mengarahkan anak sesuai dengan tahap perkembangan anak, sehingga anak tidak berkembang secara optimal. Sejauh apa yang dipahami orang tua tentang mendidik anak demikianlah mereka akan

\footnotetext{
${ }^{14}$ Kartini Kartono, Pengantar Ilmu Mendidik Teoritis ( Bandung: Mandar Maju , 1992 ), 115 - 17.

${ }^{15}$ Soemiarti Padmonodewo, Pendidikan Anak Prasekolah (Jakarta : Rineka Cipta, 2003 ), 83
} 
memperlakukan anak dalam keluarga. Dengan pendidikan yang memadai orang tua dapat memperoleh perkerjaan yang baik sehingga penghasilan cukup memenuhi kebutuhan.

Djarinah mengatakan:

Orang tua yang berpenghasilan rendah akan menuntut waktu untuk bekerja lebih banyak, seorang ibu harus ikut bekerja untuk mendapatkan uang agar dapat mencukupi kebutuhan keluarga karena penghasilan suami tidak mencukupi semua kebutuhan di rumah. Ibu rumah tangga yang seharusnya lebih banyak tinggal di rumah untuk mendampingi anak-anak harus bekerja menopang ekonomi keluarga. ${ }^{16}$

Dalam banyak hal kemiskinan suatu keluarga merupakan penyebab utama kebutuhan tidak cukup, kesehatan jelek, juga dapat menimbulkan perasaan rendah diri terhadap lingkungan sekitar. ${ }^{17}$ Keadaan keluarga seperti ini, dapat berakibat negatif terhadap perilaku sosialisasi anak. Anak akan sulit bergaul dan berinteraksi dengan orang lain, karena minder dan merasa tidak berharga. Kadangkala situasi ini membuat anak menarik diri dari teman-teman dan lingkungan di sekitarnya.

Adanya ayah dan ibu merupakan suatu kebanggaan bagi anak. Kehadiran orang tua sangat penting bagi mereka. Perasaan aman dan terlindungi begitu kuat ketika merasakan belaian dan kasih sayang orang tua. Apalagi di saat anak merasa ketakutan dan sedih, tidak banyak hal yang diinginkan oleh anak selain kehadiran orang tua di sisinya. Ada anak yang tidak dapat merasakan kasih sayang dan kehadiran orang tua di sisinya karena konflik yang terjadi dalam rumah tangga. Dampak konflik itu akan merembes ke seluruh anggota keluarga."18 Seringkali konflik ini akan bermuara pada perceraian. ${ }^{19}$ Menurut David: "Orang tua yang bercerai sebelum anak berusia enam tahun, dampaknya bagi anak adalah seringkali anak menyalahkan diri sendiri sebagai penyebab perceraian itu. Beberapa kemungkinan yang terjadi bagi anak akibat perceraian adalah anak menjadi lebih peka terhadap kesepian, harga diri rendah dan perasaan tidak berguna bagi orang lain: Keutuhan orang tua dapat membangun rasa percaya diri anak, rasa harga diri, dan penerimaan diri sendiri." ${ }^{20}$ Keadaan ini dapat membuat anak sulit untuk memercayai orang lain. Anaklah yang paling menderita akibat perceraian dari orang tua.

Gottman dan De Claire mengatakan:

Dalam penelitian kami menemukan bahwa konflik pernikahan memiliki dampak yang sangat besar terhadap kesehatan fisik dan emosional anak-anak, serta kemampuan mereka untuk bergaul dengan teman-teman sebayanya. Data kami memerlihatkan bahwa anak-anak yang dibesarkan oleh orang tua yang pernikahannya diwarnai celaan, permusuhan satu sama lain, serta kebencian jauh lebih cenderung menunjukkan

\footnotetext{
${ }^{16}$ Fathul Djarinah, Rustam, Nurasiah, dkk, Kekerasan Terhadap Istri (Yogyakarta: LKIS, 2003 ), 41.

${ }^{17}$ Diagram Group, Tubuh Anak (Jakarta : BPK Gunung Mulia, 1990), 426

${ }^{18}$ Paulus Mujiran, Pernik-Pernik Pendidikan (Yogyakarta: Pustaka Pelajar, 2002), 34

${ }^{19}$ Ibid.

${ }^{20}$ David O.Sears, L.Freedman, L.Anne Peplau, Psikologi Sosial ( Jakarta: Erlangga, 1988 ), 214
} 
perilaku anti sosial dan agressi terhadap teman-teman bermain mereka. Mereka memiliki lebih banyak kesulitan untuk mengatur emosi, memfokuskan perhatian, serta menenangkan diri mereka ketika sedang kacau.. Kami membandingkan data dari sesisesi bermain itu dengan informasi yang kami dapat dari keluarga-keluarga dalam wawancara dan percobaan laboratorium. Kami menemukan hubungan yang kuat antara pernikahan dan perilaku anak-anak dengan teman-teman mereka. Anak-anak yang orang tuanya mengalami masalah dalam pernikahan, kurang bekerja sama bermain dan memiliki lebih banyak interaksi negatif dengan teman bermain mereka dari pada anakanak yang orang tuanya memiliki pernikahan bahagia. ${ }^{21}$

Menurut Anita Lie: "Kehidupan rumah tangga yang hangat dan hubungan antar keluarga yang erat akan memberikan rasa aman bagi anak. Selanjutnya rasa aman ini memungkinkan anak memperoleh modal dasar percaya diri." 22 Rasa percaya diri menolong anak dalam membangun relasi dengan orang lain dan mempermudah anak untuk berinteraksi dengan orang-orang di sekitarnya. Menurut Wright: “Anggota keluarga yang saling memperhatikan, mengungkapkan perhatian dan kasih sayang dengan perkataan, menikmati kebersamaan, berkumpul tidak hanya karena kewajiban dan anggota keluarga dapat tertawa bersama, saling membagikan harapan, impian, ketakutan, kecemasan dan tetap diterima." 23 Situasi keluarga yang seperti ini mendorong dan melatih anak untuk mengungkapkan perasaan dengan luwes dan tempat belajar untuk dapat menerima orang lain apa adanya.

Keluarga yang mempunyai banyak anak membutuhkan biaya yang besar untuk memenuhi kebutuhan hidup sehari-hari. Jika penghasilan orang tua besar dan mencukupi, jumlah anak banyak tidak menjadi masalah. Tetapi jika penghasilan orang tua kecil maka kebutuhan anak sulit terpenuhi. Beban orang tua menjadi sangat berat. Perhatian terhadap anak pun tidak maksimal karena harus membagi kepada banyak anak. Orang tua dapat kewalahan dengan sifat anak yang berbeda-beda serta keinginan yang bermacam-macam. Anak merasa kurang diperhatikan dan disayangi apabila keinginan mereka tidak pernah terpenuhi. Mereka menjadi kecewa, sakit hati, marah, dan keadaan ini dapat memengaruhi perkembangan mental serta emosi anak, dan berdampak pada perilaku sosialnya.

\section{METODOLOGI PENELITIAN}

Metode yang digunakan dalam penelitian ini adalah metode deskriptif kualitatif. Metode kualitatif adalah: "Metode penelitian yang menghasilkan data deskriptif berupa kata-kata tertulis atau lisan dari orang-orang dan perilaku yang dapat diamati." 24 Sampel penelitian adalah 15 orang anak TK Bina Kasih. Sampel yang diambil adalah anak yang

\footnotetext{
${ }^{21}$ John Gottman dan Juan DeClaire, Mengasuh Anak Dengan Hati (Yogyakarta: Prisma Media, 2004), $175-176$.

${ }^{22}$ Anita Lie, 101 Cara Menumbuhkan Percaya Diri Anak, (Jakarta: Elex Media Komputindo, 2003 ), 82

${ }^{23}$ H. Norman Wright, Menjadi Orang Tua Bijaksana (Yogyakarta: Yayasan Andi Offset Tahun 2003), 26

${ }^{24}$ Lexy J. Moleong, Metodologi Penelitian Kualitatif, (Bandung: PT Remaja Rosdakarya, 1989), 3
} 
masuk di tahun ajaran baru, untuk mendapatkan keberadaan anak yang lebih akurat karena langsung dari keluarga. Belum dipengaruhi oleh didikan di sekolah yang mengaburkan perilaku asli anak. Teknik pengumpulan data melalui observasi dalam bentuk list, observasi secara langsung oleh Peneliti di TK Bina Kasih, observasi guru dan wawancara terhadap orang tua.

Pengumpulan data melalui Lembar pengamatan dalam bentuk checklist oleh peneliti, guru dan wawancara kepada orang tua. Checklist merupakan suatu daftar yang berisi namanama subjek dan faktor-faktor yang akan diselidiki. ${ }^{25}$ Pengamatan dalam bentuk checklist diisi setiap hari, selama tiga puluh hari pengamatan. Pengamatan yang dilakukan terhadap anak adalah untuk memperoleh gambaran perilaku sosialisasi anak usia 4-6 tahun, khususnya 15 anak tersebut. Perilaku sosialisasi anak dalam hal penyesuaian sosial, kooperatif, simpati dan empati, berteman, dan sopan santun yang dijabarkan dalam delapan poin untuk setiap perilaku sehingga seluruhnya ada 40 item.

Dasar pemikiran penjabaran poin-poin ini sebagai bahan pengamatan karena pola perilaku sosialisasi anak dapat dikembangkan dan diukur melalui poin-poin tersebut; hal ini sebagaimana dijelaskan oleh Hurlock. ${ }^{26}$ Pengamatan dilakukan langsung di TK Bina Kasih Terpadu baik sebelum anak masuk kelas, saat belajar, pada saat makan bersama dan saat bermain di dalam dan di luar kelas selama 30 hari dalam tiga tahap. Latar belakang keluarga yang dimaksud dalam penelitian ini adalah: pendidikan orang tua, penghasilan, pekerjaan, keutuhan keluarga, dan jumlah anak. Data latar belakang orang tua akan didapatkan dari guru TK, dari data anak yang ada di TK. Pengamatan oleh Peneliti dilakukan tiga tahap, setiap tahap adalah 10 hari, jadi 3 tahap adalah 30 hari, sedangkan pengamatan oleh guru dilakukan dua tahap. Setiap hari pengamatan membuat checklist yang ada aspek perbuatannya. Setelah 10 hari dihitung setiap perilaku, demikian dilakukan untuk tiga tahap dan yang dihitung adalah tanda chek yang ada pada perilaku.

Penghitungan: hasil 3 tahap pengamatan dijumlahkan lalu dibagi tiga, pengamatan guru dibagi dua itu merupakan hasil akhir dan dijadikan sebagai penentu perilaku sosialisasi anak. Scoring pengamatan adalah sebagai berikut:

- Setelah mendapatkan data melalui checklist setiap perilaku yang diberi tanda check diberi tabel nilai;

- Nilai setiap poin adalah 1 dan nilai pengulangan adalah 1 ;

- Kemudian dijumlahkan (8X10 pengulangan = 80) dalam satu tahap pengamatan;

- (10 hari) untuk satu perilaku sosial;

- Lima perilaku sosialisasi $\left.\frac{(80+80+80+80+80}{5}=80\right)$, untuk satu tahap;

pengamatan. Penghitungan yang sama dilakukan untuk tahap kedua dan ketiga;

\footnotetext{
${ }^{25}$ Sutrisno Hadi, MA, Metodologi Research Jilid II, ( Yogyakarta : Andi Offset, 2000 ), 151

${ }^{26}$ Hurlock, Psikologi Perkembangan Jilid II, 262
} 
- Tiga tahap pengamatan = nilai setiap tahap dijumlahkan lalu dibagi tiga

$-\left(\frac{80+80+80}{3}=80\right)$, nilai ini yang dipakai untuk menentukan kategori perilaku sosialisasi anak.

- Nilai dikonversi ke $100 \%=\frac{80}{80} \times 100 \%=100$

Standar yang digunakan untuk menentukan perilaku sosialisasi anak adalah: 75-100 Perilaku sosialisasi baik (B); 45-74 Perilaku sosialisasi cukup (C); 25-44 Perilaku sosialisasi kurang (B).

\section{HASIL DAN PEMBAHASAN}

Untuk mendapatkan keadaan perilaku sosialisasi anak maka dilakukan pengamatan dan wawancara. Pengamatan kepada anak baik oleh peneliti maupun oleh guru yang mengajar di TK Bina Kasih Terpadu. Mengikutsertakan guru dalam pengamatan untuk mendapatkan data yang lebih akurat. Pengamatan menggunakan kuesioner yang dijabarkan dari lima perilaku sosialisasi, masing-masing perilaku sosialisasi menjadi 8 item sehingga keseluruhan menjadi 40 indikator. Kuesioner yang digunakan oleh Peneliti dan Guru adalah sama. Pengamatan yang dilakukan adalah untuk mengetahui perilaku sosialisasi 15 anak di TK Bina Kasih. Keberadaan anak di rumah serta latar belakang keluarga didapatkan melalui data anak di sekolah juga melalui hasil wawancara dengan orang tua anak. Setelah melakukan pengamatan tiga tahap oleh Peneliti dan dua tahap oleh Guru maka ditemukan perilaku sosialisasi anak sebagai berikut:

Tabel Perilaku Sosialisasi Anak

\begin{tabular}{|c|c|c|c|}
\hline Nama Anak & Pengamatan Peneliti & Pengamatan Guru & Perilaku Sosialisasi \\
\hline $\mathrm{AC}$ & 91,9 & 90 & $\mathrm{~B}$ \\
\hline $\mathrm{AB}$ & 30,6 & 31,3 & $\mathrm{~K}$ \\
\hline $\mathrm{AN}$ & 95,8 & 85 & $\mathrm{~B}$ \\
\hline BAS & 96,3 & 90 & $\mathrm{~B}$ \\
\hline DLF & 44,2 & 38,8 & $\mathrm{~K}$ \\
\hline ET & 58,8 & 53,8 & $\mathrm{C}$ \\
\hline LS & 96 & 88,8 & $\mathrm{~B}$ \\
\hline MEG & 84,1 & 81,3 & $\mathrm{~B}$ \\
\hline NTA & 43,7 & 40 & $\mathrm{~K}$ \\
\hline $\mathrm{PN}$ & 44,1 & 38,8 & $\mathrm{~K}$ \\
\hline PR & 93,9 & 84,8 & $\mathrm{~B}$ \\
\hline RAK & 51,2 & 51,3 & $\mathrm{C}$ \\
\hline RT & 59,1 & 52,5 & $\mathrm{C}$ \\
\hline VST & 35,8 & 28,8 & $\mathrm{~K}$ \\
\hline $\mathrm{VS}$ & 59,1 & 66,3 & $\mathrm{C}$ \\
\hline
\end{tabular}


Hasil pengamatan Peneliti dan Guru terhadap 15 anak adalah sama. Hasil penelitian dari 15 orang sampel ditemukan ada 6 orang anak $40 \%$ masuk kategori perilaku sosialisasi baik, 4 orang 26,7\% masuk perilaku sosialisasi cukup, 5 orang 33,3\% kategori perilaku sosialisasi kurang. Dari hasil wawancara dengan orang tua, diketahui keadaan anak dan cara orang tua memperlakukan anak di rumah.

Latar Belakang Keluarga dan Perilaku Sosialisasi Anak

\begin{tabular}{|c|c|c|c|c|c|c|c|c|}
\hline \multirow{2}{*}{$\begin{array}{l}\text { Nama } \\
\text { Anak }\end{array}$} & \multirow{2}{*}{$\begin{array}{c}\text { Pendidikan } \\
\text { orang tua }\end{array}$} & \multirow{2}{*}{ Pekerjaan } & \multirow{2}{*}{$\begin{array}{l}\text { Penghasilan/ } \\
\text { Bulan (Rp) }\end{array}$} & \multirow{2}{*}{$\begin{array}{c}\text { Jumlah } \\
\text { Anak dalam } \\
\text { Keluarga }\end{array}$} & \multirow{2}{*}{$\begin{array}{c}\text { Keutuhan } \\
\text { Keluarga }\end{array}$} & \multicolumn{2}{|c|}{ Jumlah Rata-Rata } & \multirow{2}{*}{$\begin{array}{c}\text { Perilaku } \\
\text { Sosialisasi }\end{array}$} \\
\hline & & & & & & $\begin{array}{c}\text { Pengamatan } \\
\text { Peneliti }\end{array}$ & $\begin{array}{c}\text { Pengamatan } \\
\text { Guru }\end{array}$ & \\
\hline $\mathrm{AC}$ & $\begin{array}{c}\text { SLTA } \\
\text { Dipl. II }\end{array}$ & $\begin{array}{c}\text { Wiraswasta, } \\
\text { PNS }\end{array}$ & 2 Juta & 3 orang & Bercerai & 91,9 & 90 & B \\
\hline $\mathrm{AB}$ & SMP & Supir & 700 Ribu & 2 orang & Bercerai & 30,6 & 1,3 & K \\
\hline AN & $\begin{array}{l}\text { SLTA } \\
\text { SLTA }\end{array}$ & $\begin{array}{c}\text { Wira } \\
\text { swasta PNS }\end{array}$ & 2 Juta & 2 Orang & Utuh & 95,8 & 85 & B \\
\hline BAS & $\begin{array}{l}\text { SLTA } \\
\text { SLTA }\end{array}$ & Bengkel & 900 Ribu & 2 Orang & Utuh & 96,3 & 90 & B \\
\hline DLF & SLTA, SD & Petani & 800 Ribu & 2 Orang & Utuh & 44,2 & 38,8 & $\mathrm{~K}$ \\
\hline ET & SD, SMP & Petani & 800 Ribu & 3 Orang & Utuh & 58,8 & 53,8 & $\mathrm{C}$ \\
\hline LS & $\begin{array}{l}\text { DipL.II } \\
\text { SLTA }\end{array}$ & $\begin{array}{c}\text { PNS, } \\
\text { Wiraswasta }\end{array}$ & 2 Juta & 2 Orang & Utuh & 96 & 88,8 & B \\
\hline MEG & $\begin{array}{l}\text { S.Pd } \\
\text { SPK }\end{array}$ & $\mid \begin{array}{c}\text { PNS } \\
\text { Wiraswasta }\end{array}$ & 2 Juta & 2 Orang & Utuh & 84,1 & 81,3 & B \\
\hline NTA & $\begin{array}{c}\text { SMP } \\
\text { SLTA }\end{array}$ & $\begin{array}{l}\text { Tukang } \\
\text { Petani }\end{array}$ & 1 Juta & 4 Orang & Utuh & 43,7 & 40 & K \\
\hline PN & $\begin{array}{c}\text { SMP } \\
\text { SLTA }\end{array}$ & $\begin{array}{c}\text { Supir } \\
\text { Petani }\end{array}$ & 800 Ribu & 2 Orang & Utuh & 44,1 & 38,8 & K \\
\hline PR & $\begin{array}{l}\text { SLTA } \\
\text { SLTA }\end{array}$ & $\begin{array}{l}\text { PNS } \\
\text { PNS }\end{array}$ & 3 Juta & 3 Orang & Utuh & 93,9 & 84,8 & B \\
\hline RAK & $\begin{array}{c}\text { SMP } \\
\text { SLTA }\end{array}$ & Wiraswasta & 1 Juta & 1 Orang & Utuh & 51,2 & 51,3 & $\mathrm{C}$ \\
\hline RT & $\begin{array}{l}\text { SLTA } \\
\text { SLTA }\end{array}$ & $\begin{array}{c}\text { Pegawai } \\
\text { swasta }\end{array}$ & 1 Juta & 2 Orang & Utuh & 58,5 & 52,5 & $\mathrm{C}$ \\
\hline VST & $\begin{array}{l}\text { SLTA } \\
\text { SLTA }\end{array}$ & $\mid \begin{array}{c}\text { Peg.Swasta } \\
\text { Petani }\end{array}$ & 1 Juta & 1 Orang & Utuh & 35,8 & 28,8 & K \\
\hline VS & $\begin{array}{c}\text { SLTA } \\
\text { Dipl. III }\end{array}$ & Peg. Swasta & 2 Juta & 2 Orang & Bercerai & 59,1 & 66,3 & $\mathrm{C}$ \\
\hline
\end{tabular}


Pendidikan orang tua dalam penelitian ini sebagian besar adalah tamat SLTA, tiga orang perguruan tinggi, tetapi ada beberapa orang yang hanya tamat SMP dan SD. Hampir semua anak yang berperilaku sosialisasi baik pendidikan orang tuanya baik. Namun ada dua anak perilaku sosialisasinya cukup yaitu RT dan VS, Satu anak dengan perilaku sosialisasi kurang sekalipun pendidikan orang tuanya baik yaitu VST. Kemungkinan mengapa ketiga anak ini tidak mencapai perilaku sosialisasi baik karena dalam pola pengasuhan, orang tua tidak menerapkan pola pengasuhan yang tepat.

Orang tua yang keduanya bekerja mempunyai sedikit waktu untuk anak di rumah. Orang tua yang mengerti bahwa kehadiran mereka di samping anak adalah sebagai bentuk perhatian, dan kasih sayang serta menyadari itu penting bagi anak, khususnya saat mereka kecil tentu akan memiliki sikap yang berbeda. Pemahaman tersebut membuat orang tua berusaha membagi waktu untuk dapat berada di sisi anak. Berada bersama anak menjadi kesempatan bagi orang tua untuk mengajarkan hal-hal yang baik. Tetapi orang tua yang sibuk bekerja dan tidak memberi waktu untuk mendidik anak, maka anak tidak terarah dengan baik. Anak tidak tahu perilaku apa yang harus dilakukan. Situasi ini memungkinkan anak sulit dalam membina hubungan atau berinteraksi dengan orang lain. Orang tua yang selalu berusaha menyediakan waktu bersama dengan anak adalah orang tua $\mathrm{AC}, \mathrm{AN}$, BAS, LS, MEG, PR, dan RT. Orang tua AB, DLF, ET, NTA, PN, RAK, VST, dan VS kurang memiliki waktu bersama anak di rumah karena kesibukan pekerjaan dan tuntutan kebutuhan. RT orang tuanya selalu ada di rumah, tetapi karena RT selalu dimanja maka RT menjadi anak yang sulit untuk menyesuaikan diri dengan teman dan lingkungan baru.

Penghasilan rendah dalam keluarga menuntut orang tua harus mencari pekerjaan lain supaya kebutuhan dapat terpenuhi. Akibatnya orang tua tidak memunyai banyak waktu untuk anak. Anak ditinggal demi kebutuhan yang harus dipenuhi. Anak kembali menjadi korban dari kecilnya penghasilan. Tidak jarang terjadi seorang ibu harus ikut mencari pekerjaan tambahan supaya kebutuhan di rumah dapat tercukupi. Seorang ibu seharusnya lebih banyak di rumah untuk mendampingi anak. Bagi orang tua yang penghasilannya dapat mencukupi kebutuhan keluarga maka waktu bersama dengan anak menjadi lebih banyak. Orang tua dapat menggunakan waktu yang ada untuk membimbing dan mengarahkan anak supaya anak lebih siap menghadapi kehidupan yang akan datang. Dari hasil wawancara orang tua yang mengakui bahwa penghasilan sekarang cukup untuk kebutuhan keluarga adalah orang tua AC, AN, BAS, LS, MEG, PR, RAK, VST, dan VS. Sedangkan orang tua yang mengakui kurang adalah orang tua AB, DLF, ET, NTA, PN, dan RT. Ditemukan pada RAK, VST, VS sekalipun kebutuhan tercukupi, anak belum mencapai perilaku sosialisasi baik. Tidak cukup hanya kebutuhan saja yang tercukupi, ada hal lain dalam keluarga yang turut menunjang dalam pembentukan perilaku anak tetapi tidak didapatkan oleh anak. 
Keutuhan orang tua memungkinkan pemberian kasih sayang dan perhatian yang utuh kepada anak. Anak tidak hanya butuh kasih sayang seorang ayah atau ibu tetapi keduaduanya. Perhatian dan kasih sayang dari orang tua adalah kebutuhan yang amat penting bagi anak terlebih saat anak masih kecil. Anak merasa aman, terlindungi berada di samping orang tuanya. Jika orang tua bercerai kebutuhan tersebut tidak akan terpenuhi bagi anak. Keadaan ini dapat membuat anak rendah diri dan perasaan tidak berguna bagi orang lain. Bagaimana anak dapat merasa berharga sedangkan orang yang seharusnya mengasihi mereka tidak memerdulikannya. Tidak merasakan kasih sayang di rumah dapat berdampak bagi anak sehingga tidak dapat mengasihi orang lain. Keadaan ini sangat terlihat dalam diri $\mathrm{AB}$ anak yang kedua orang tuanya bercerai. Ayah serta nenek yang mengasuhnya kurang memerhatikan keadaannya. Kalau anak tidak dapat mengasihi, ada kemungkinan sulit untuk diterima ketika bersama dengan orang lain. AB juga kurang mengasihi teman-temannya, dia selalu menganggu, suka memukul, dan sering membuat jengkel sehingga anak-anak lain tidak senang bermain dengannya.

$\mathrm{AC}$ dan VS agak berbeda dengan AB. Kemungkinan karena AC mendapat arahan, bimbingan dan pengasuhan yang tepat dari kakek nenek dalam keluarga yang utuh, sehingga perilaku sosialnya terbina dengan baik. AC juga sangat disenangi oleh temantemannya, perkataan dan idenya sering diikuti oleh anak-anak lain. VS memang diasuh dalam keluarga yang utuh tetapi kurang mendapat perhatian dan kasih sayang, sehingga VS dalam pengamatan cenderung masa bodoh, kurang peduli terhadap teman-temannya, dan bermain hanya dengan orang-orang tertentu saja. Jadi anak yang memiliki orang tua utuh adalah AN, BAS, DLF, ET, LS, MEG, NTA, PN, PR, RAK, RT, VST dan anak yang orang tuanya bercerai adalah $\mathrm{AC}, \mathrm{AB}$, dan VS.

Orang tua yang mempunyai banyak anak akan sulit membagi perhatian dan kasih sayang. Apalagi anak-anak memiliki keinginan yang berbeda-beda. Selain itu kebutuhan yang diperlukan juga akan lebih besar dibanding dengan keluarga yang memunyai sedikit anak. Kurangnya perhatian dan kebutuhan dapat membentuk anak menjadi seorang yang tidak dapat memerhatikan orang lain dan tidak mengerti keinginan orang lain. Orang tua yang memunyai banyak anak adalah orang tua ET, NTA, dan PR. Orang tua ET dan NTA berpenghasilan rendah sehingga kurang mencukupi kebutuhan sehari-hari. Kedua anak ini terlihat minder, tetapi ET dari hari kesehari mulai terlihat perubahan. Dia sudah lebih berani, mau maju ke depan kelas melakukan kegiatan yang diperintahkan guru, dan mau bermain bersama. NTA sampai hari terakhir pengamatan tidak mau bermain bersama, tidak berani maju ke depan kelas dan sulit diajak berbicara. PR walaupun mereka tiga bersaudara, penghasilan orang tua cukup memenuhi kebutuhan. Orang tua selalu mendampingi perkembangan anak, juga menanamkan kebiasaan-kebiasaan yang baik kepada anak sehingga anak bertumbuh dalam perilaku yang baik. 


\section{Perilaku Sosialisasi Anak}

Perilaku sosialisasi ini penting bagi semua orang, tidak hanya untuk orang dewasa saja bagi anak-anak juga. Orang tua yang berpendidikan setidaknya memiliki dasar pengetahuan untuk mendidik, membina anak lebih baik karena pernah mengalami dididik dan dibina oleh guru di sekolah. Sebagaimana yang dikatakan oleh dengan adanya pendidikan yang dimiliki oleh orang tua, berarti peran dan tanggung jawab menjadi lebih baik. Mereka juga lebih berpengetahuan untuk mempersiapkan anak mengahadapi dunia yang lebih luas, dimana terdapat ragam budaya dan kebiasaan yang berbeda. Pendidikan orang tua turut menentukan sikap dan tindakan yang akan dilakukan terhadap anak yang diasuh. Selain pendidikan, keadaan ekonomi, pekerjaan, ketuhan keluarga dan jumlah anak merupakan bagian yang penting dalam menunjang kedua orang tua memperlakukan anak di rumah.

Anak yang dibiasakan dengan hal-hal baik di rumah berarti sedang membekali anak memiliki perilaku yang baik di tengah-tengah masyarakat. Kebiasaan itu dapat membentuk karakter anak, yang akan dibawa keluar rumah saat anak mulai berhubungan dengan orang lain. Keadaan ini juga menolong anak ketika berinteraksi dengan orang lain, baik dengan sesama anak-anak maupun dengan orang dewasa.

Berdasarkan hasil pengamatan langsung dan pengamaan Guru maka ditemukan enam orang (AC, AN, BAS, LS, MEG, PR) yang masuk kriteria perilaku sosialisasi baik secara keseluruhan memiliki latar belakang keluarga yang baik. Kecuali BAS dimana penghasilan orang tua rendah tetapi bimbingan dan pendampingan orang tua yang tepat membuat pertumbuhan perilaku sosialisasi BAS berkembang dengan baik. Keadaan ini menunjukkan adanya pengaruh latar belakang keluarga dengan perilaku sosialisasi anak.

Empat orang anak dengan perilaku sosialisasi cukup (ET, KAK RT, VS) dari latar belakang keluarga ada beberapa hal yang tidak mendukung dengan baik sehingga perilaku anakpun hanya mencapai perilaku sosialisasi cukup. Ada lima orang anak (AB, DLF, NTA, PN, VST) perilaku sosialisasi kurang sebagian besar latar belakang keluarga tidak mendukung pertumbuhan dan perkembangan perilaku sosialisasi. Tetapi VST pendidikan orang tua, penghasilan, pekerjaan, keutuhan keluarga sangat mendukung, tetapi yang menjadi masalah adalah pola asuh yang diterapkan orang tua adalah memanjakan anak sehingga anak menjadi egois, cengeng, sulit berpisah dengan orang tua, tidak mau berbagi mainan. Hal ini menunjukkan bahwa kemampuan dan ketidakmampuan anak berperilaku sosialisasi baik sangat besar kaitannya dengan latar belakang keluarga anak.

\section{KESIMPULAN}

Dalam penelitian ini menemukan ada hubungan latar belakang keluarga dengan perilaku sosialisasi anak, terlihat jika latar belakang keluarga (pendidikan, penghasilan, pekerjaan, keutuhan, keluarga, pola asuh baik dan tepat maka ditemukan anak dengan 
perilaku sosial yang baik. Walaupun pendidikan, pekerjaan penghasilan baik namun erilaku sosialisasi anak tidak masuk kategori baik karena atidak dilengkapi dengan keutuhan orang tua dan pola asuh yang tepat. Hal ini menunjukkan bahwa pendampingan orang tua dalam masa-masa pembentukan perilaku sosial anak mempunyai peran yang sangat penting dan perlu diperhatikan karena ikut menentukan berhasil tidaknya orang tua mendidik dan mempersiapkan anak untuk hidup dalam lingkungan yang lebih kompleks dengan temanteman sebaya dan masyarakat luas. Anak yang latar belakang keluarganya kurang mendukung pekembangan anak sehingga anak masih kategori PS kurang, tetapi anak ini memiliki keistimewaan yang idak dimiliki oleh anak lain yaitu dalam hal kemandirin. Anak ini beangkat ke TK dan pulang sekolah tidak didampingi oleh orang tua seperti anak lain. Tidak cengeng hari pertama sekolah, tidak menangis dan mau ditinggal oleh orang tuanya.

Ada dua anak dalam penelitian ini di mana latar belakang pendidikan orang tua, penghasilan cukup, keluarga utuh, namun anak tidak masuk kategori PS baik, karena di dalam mendidik anak orang tua menerapkan pola asuh pemanja. Sehingga anak sampai kuang lebih 3 minngu tidak mau ditinggal orang tua di TK. Anak cengeng, tidak mau berbagi makanan dan mainan, egois bahkan VST mudah sekali baginya ntuk memukul teman dan guru apabila tidak menuruti keinginannya, dia juga suka omong kotor. Setelah masuk di TK secara umum anak mengalami kemajuan yang baik dalam perilaku sosialnya. Karena sifat anak yang mudah dipengaruhi oleh lingkungan dimana ia berada. Hal ini dialami oleh anak-anak di TK Bina Kasih setelah mereka di TK.

Perubahan ini dikarenakan pendidikan yang diberikan guru kepada anak sehingga mengetahui perilaku apa yang pantas dilakukan dan apa yang tidak; situasi TK dikondisikan sedemikian rupa, melatih anak untuk mau tidak mau harus mengikuti ketentuan yang ada di TK; penerapan disiplin yang tegas dan konsisten membuat anak tidak mengulang kesalahan yang sama; pembiasaan yang dilakukan terus menerus dari hari ke hari membuat anak memiliki kebiasaan yang baik; ada batasan yang jelas antara hal yang dapat dilakukan dengan yang tidak dapat dilakukan; lingkungan yang baik akan mempengaruhi anak melakukan yang baik pula, karena itu orang tua harus memperhatikan lingkungan anak di rumah dan juga sekolah tempat anak belajar agar lingkungan ini turut membantu mempersiapkan anak memasuki dunia yang lebih luas.

\section{REFERENSI}

Departemen Pendidikan Nasional.. Kamus Besar Bahasa Indonesia, Jakarta:Balai Pustaka, 2001.

Diagram Group.. Tubuh Anak, Jakarta: BPK Gunung Mulia, 1990.

Djarinah, Fathul, dkk. Kekerasan Terhadap Istri, Yogyakarta: LKIS, 2003. 
Gottman, Jhon \& DeClaire, Juan. Mengasuh Anak Dengan Hati, Yogyakarta: Prisma Media, 2004.

Gunarsa, D, Singgih. Dasar dan Teori Perkembangan Anak, Jakarta: BPK Gunung Mulia1997 2004.

Hadi, Sutrisno. Metodologi Research Jilid I, Yogyakarta: Andi Offset, 2000. . Metodologi Research Jilid II, Yogyakarta: Andi Offset, 2000.

Hadisubrata, MS. Mengembangkan Kepribadian Anak, Jakarta: BPK Gunung Mulia, 1991.

Hurlock, B, Elisabeth. Psikologi Perkembangan Jilid I, Jakarta: Erlangga, 2003. . Psikologi Perkembangan Jilid II, Jakarta: Erlangga, 2004.

Kartono, Kartini. Pengantar Ilmu Mendidik Teoritis, Bandung: Mandar Maju, 1992. Lie, Anita. 101 Menumbuhkan Percaya Diri, Jakarta: PT Elex Media Komputindo, 2003. Moleong, Lexi. Metodologi Penelitian Kualitatif, Bandung: PT remaja Rosdakarya, 1989. Mujiran, Paulus. Pernik-Pernik Pendidikan, Yogyakarta: Pustaka Pelajar, 2002.

Padmonodewo, Soemiarti. Pendidikan Anak Prasekolah, Jakarta: Rineka Cipta, 2003. Prasetiyo, T, George. Smart Parenting, Jakarta: PT Elex Media Komputindo, 2006. Rimm, Sylvia. Mendidik dan Menerapkan Disiplin Pada Anak Prasekolah, Jakarta: Gramedia Pustaka Utama, 2003.

Sears, O, David, Fredman, L \& Peplau, L, Anne. Psikologi Sosial, Jakarta: Erlangga, 1988. Surya, Hendra.. Percaya Diri itu Penting, Jakarta: PT Elex Media Komputindo, 2007. Wijanarko, Jarot.. Anak Cerdas Berakhlak, Jakarta: Happy Holy Kids, 2007.

Wiriadmaja, Soekandar.. Pokok-Pokok Sosiologi Pedesaan, Bandung: CV Yasa Guna, 1987.

Wright, H, Norman. Menjadi Orang Tua Yang Bijaksana, Yogyakarta: Andi Offset, 2003. Hasugian, Johanes Waldes. "Kurikulum Pendidikan Kristen Bagi Orang Dewasa Di Gereja." Kurios: Jurnal Teologi dan Pendidikan Agama Kristen 5, no. 1 (2019): 3654.

Hasugian, Johanes Waldes, Suardin Gaurifa, Sipora Blandina Warella, Jusuf Haries Kelelufna, and Josefien Waas. "Education for Children with Special Needs in Indonesia.” Journal of Physics: Conference Series 1175, no. 1 (2019). 